\title{
Re-identification of c. 15700 cal yr BP tephra bed at Kaipo Bog, eastern North Island: implications for dispersal of Rotorua and Puketarata tephra beds
}

\author{
PHIL SHANE \\ VICTORIA C. SMITH \\ Department of Geology \\ University of Auckland \\ Private Bag 92019 \\ Auckland, New Zealand \\ email: pa.shane@auckland.ac.nz

\section{DAVID J. LOWE} \\ Department of Earth Sciences \\ University of Waikato \\ Private Bag 3105 \\ Hamilton, New Zealand

\section{IAN NAIRN} \\ 45 Summit Rd \\ RD5, Rotorua, New Zealand
}

\begin{abstract}
A $10 \mathrm{~mm}$ thick, c. 15700 calendar yr BP (c. $13100{ }^{14} \mathrm{C}$ yr BP) rhyolitic tephra bed in the well-studied montane Kaipo Bog sequence of eastern North Island was previously correlated with Maroa-derived Puketarata Tephra. We revise this correlation to Okataina-derived Rotorua Tephra based on new compositional data from biotite phenocrysts and glass. The new correlation limits the known dispersal of Puketarata Tephra (sensu stricto, c. $16800 \mathrm{cal}$ $\mathrm{yr}$ BP) and eliminates requirements to either reassess its age or to invoke dual Puketarata eruptive events. Our data show that Rotorua Tephra comprises two glass-shard types: an early-erupted low- $\mathrm{K}_{2} \mathrm{O}$ type that was dispersed mostly to the northwest, and a high- $\mathrm{K}_{2} \mathrm{O}$ type dispersed mostly to the south and southeast, contemporary with late-stage lava extrusion. Late-stage Rotorua eruptives contain biotite that is enriched in $\mathrm{FeO}$ compared with biotite from Puketarata pyroclastics. The occurrence of Rotorua Tephra in Kaipo Bog (100 km from the source) substantially extends its known distribution to the southeast. Our analyses demonstrate that unrecognised syn-eruption compositional and dispersal changes can cause errors in fingerprinting tephra deposits. However, the compositional complexity, once recognised, provides additional fingerprinting criteria, and also documents magmatic and dispersal processes.
\end{abstract}

Keywords tephra; stratigraphy; tephrochronology; correlation; Rotorua Tephra; Puketarata Tephra; Okataina; Maroa; Kaipo; rhyolite; biotite; glass chemistry

G02053; Online publication date 13 November 2003 Received 7 October 2002; accepted 30 July 2003

\section{INTRODUCTION}

An 18000 calendar (cal) year long sequence of peat and mud interbedded with 16 rhyolitic and andesitic tephra beds is exposed at Kaipo Bog, near Lake Waikaremoana, in eastern North Island, New Zealand (Fig. 1A). This sequence has been the subject of detailed tephrostratigraphic and radiocarbon studies (Lowe \& Hogg 1986; Lowe et al. 1999) because it brackets the transition from the Last Glacial to the Holocene in a montane area considered sensitive to paleoclimatic changes (Newnham \& Lowe 2000). A c. $10 \mathrm{~mm}$ thick rhyolite tephra bed within the Kaipo sequence lies between Rerewhakaaitu and Waiohau Tephras, both erupted from the Okataina Volcanic Centre (OVC) (Fig. 1), but was assigned to the Puketarata Tephra primarily on the basis of its glass chemistry and abundant biotite (Lowe et al. 1999). However, a radiocarbon age of $13420 \pm 80{ }^{14} \mathrm{C}$ yr BP (Waikato radiocarbon age, Wk-5163) on a peat slice from $4 \mathrm{~cm}$ beneath the tephra bed is at odds with the previously estimated c. $14000{ }^{14} \mathrm{C}$ yr BP age for distal Puketarata Tephra (Lowe 1988a). Consequently, Lowe et al. (1999) suggested that either the previous age estimate on Puketarata Tephra was too old or that perhaps two compositionally similar tephra layers were erupted at c. 14000 and c. $13000{ }^{14} \mathrm{C}$ yr BP from the Puketarata source at the Maroa Volcanic Centre (Fig. 1).

Here we focus on the identification of the tephra bed from Kaipo Bog. The bed has an estimated age of c. $13100{ }^{14} \mathrm{C}$ yr BP when adjusted for the sedimentation rate in the bog (Lowe et al. 1999), equivalent to c. 15700 cal yr BP (based on the calibration dataset of Stuiver et al. 1998). The identification of this tephra at Kaipo is significant because Puketarata Tephra has not been directly dated near its source (described by Lloyd 1972; Wilson et al. 1986; Brooker et al. 1993), and little is known about its distal dispersal. Rotorua Tephra, from OVC (Nairn 1980), was also erupted at c. $13000{ }^{14} \mathrm{C}$ yr BP (= c. 15700 cal yr BP). Although the $15700 \mathrm{cal}$ yr BP tephra at Kaipo was initially thought to be Rotorua Tephra, based on its stratigraphic position and mineralogy, this correlation was rejected in favour of Puketarata Tephra because of the Kaipo bed's high $\mathrm{K}_{2} \mathrm{O}$, and low $\mathrm{TiO}_{2}$ and $\mathrm{MgO}$, glass chemistry (Lowe et al. 1999). New geochemical data, reported below, show that this high $-\mathrm{K}_{2} \mathrm{O}$ glass is in fact a component of Rotorua Tephra.

\section{GEOCHEMICAL FINGERPRINTING}

\section{Glass composition}

Rotorua Tephra was erupted from OVC vents near Lake Tikitapu (Nairn 1980) (Fig. 1B). Previous studies have shown that it has a distinctive glass composition with high $\mathrm{FeO}$ and $\mathrm{CaO}(>1.2 \mathrm{wt} \%)$ and relatively low $\mathrm{K}_{2} \mathrm{O}$ (c. $3 \mathrm{wt} \%$ ), in comparison with other OVC-derived high-silica rhyolite tephra beds (e.g., Lowe 1988b). Rotorua Tephra has a 


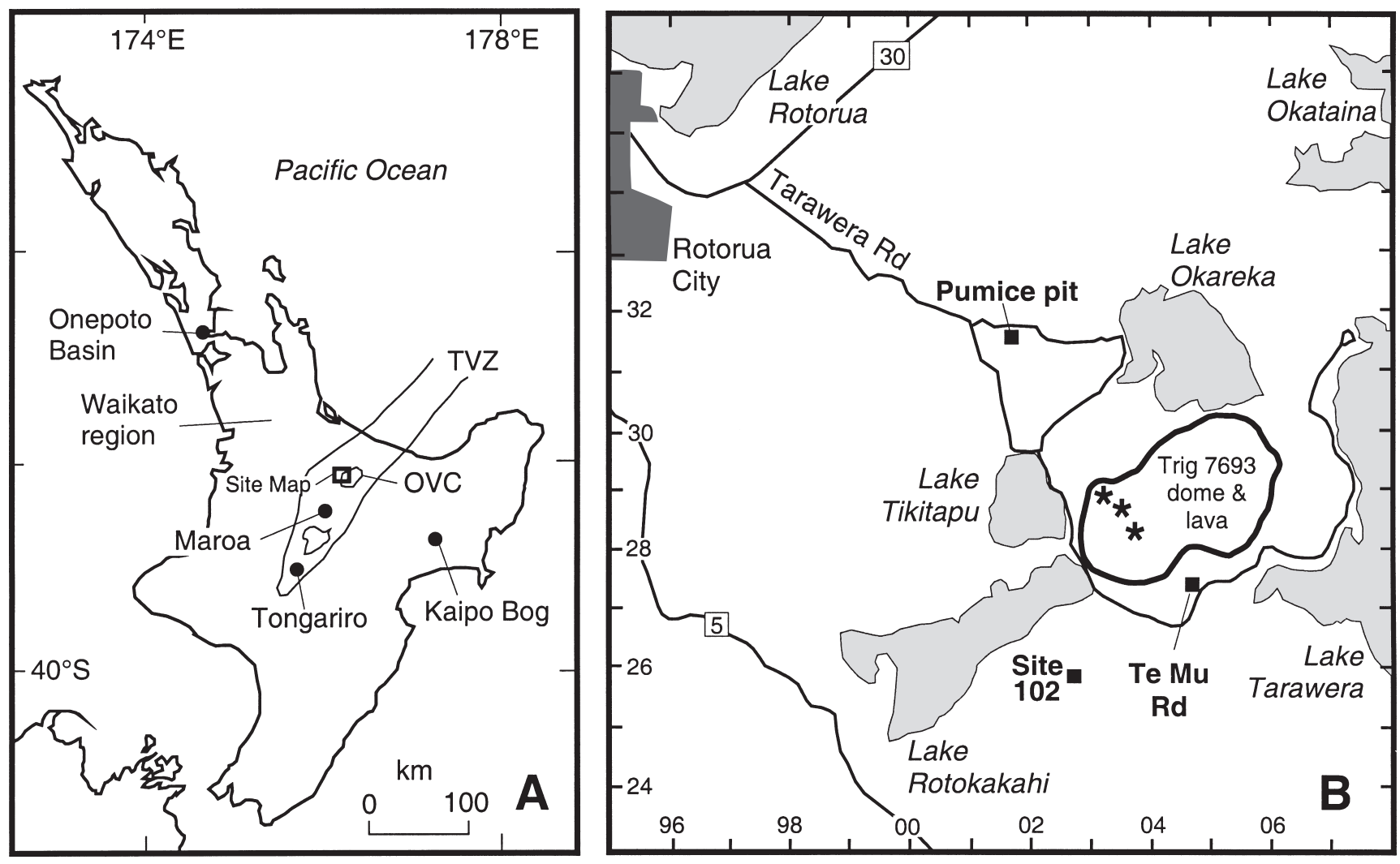

Fig. 1 A, North Island, New Zealand, showing localities referred to in text. B, The proximal area of Rotorua Tephra within the central Taupo Volcanic Zone (TVZ) showing sample sites. OVC = Okataina Volcanic Centre. Grid from sheet U16 of New Zealand Map Series 260 (1: 50 000).

hypersthene + hornblende + augite ferromagnesian mineral assemblage (FMA) (Froggatt \& Lowe 1990), and a relatively high eruption temperature $\left(\mathrm{c} .850^{\circ} \mathrm{C}\right)$ has been estimated from Fe-Ti oxide data (Shane 1998). However, biotite has been recorded in the upper part of proximal Rotorua fall sequences (Froggatt \& Lowe 1990). Biotite is common in distal Rotorua fall deposits, such as in lake deposits in the Waikato region, where it comprises c. $10 \%$ of FMA (Lowe 1988a), and in Onepoto Basin in Auckland (Fig. 1), some $160 \mathrm{~km}$ northwest from vent (Shane \& Hoverd 2002). The presence of biotite is not consistent with the high eruption temperature and low $\mathrm{K}_{2} \mathrm{O}$ glass contents of the Rotorua Tephra.

Samples from various proximal deposits (Fig. 1B) of the Rotorua eruptive episode were analysed (Table 1): early plinian phase coarse pumice from a pumice pit c. $4 \mathrm{~km}$ northwest of the vent; lava from the late stage dome (Trig 7693) and an associated block-and-ash flow deposit near Te Mu Road; and fall clasts from site 102 c. $3 \mathrm{~km}$ south of the vent. The early phase pumice clasts (Table 1 , sample 1 ) contain low- $\mathrm{K}_{2} \mathrm{O}$ (c. 3 wt\%) glass, typical of distal deposits (e.g., Lowe 1988a,b). However, rare biotite-bearing pumice clasts are also found in the middle and upper parts of the early plinian deposits at the pumice pit (first noted by Allen 1988), with the uppermost deposits dominated by biotite-bearing lapilli. Rotorua fall deposits south of the vent (e.g., site 102, Fig. 1) are composed mostly of these biotite-bearing clasts, with glass (Table 1, sample 2; Fig. 2A) that is $\mathrm{K}_{2} \mathrm{O}$-rich $(>4 \mathrm{wt} \%)$ and with a higher $\mathrm{SiO}_{2}$ content than the early erupted pumice. The biotite-bearing fall clasts are compositionally (Table 1) and mineralogically similar to the lava dome (Trig 7693) and to the block-and-ash flow deposits at Te Mu Road. Kilgour (2002) also noted two pumice/lava types based on whole-rock analyses. We also reexamined distal Rotorua Tephra from Onepoto Basin. Of the 19 shards analysed, 4 are composed of high- $\mathrm{K}_{2} \mathrm{O}$ glass, and the remainder are typically low- $\mathrm{K}_{2} \mathrm{O}$ glass (Table 1 , sample 5; Fig. 2A). This confirms the wide dispersal of products from two magma types.

We also analysed proximal-medial deposits of the Puketarata Tephra. Samples included basal and uppersequence ash and lapilli at $1 \mathrm{~km}$ from the vent (NZMS 260 grid reference U17/753900) (Table 1, sample 6); a vertical sequence through $40 \mathrm{~cm}$ of ash and fine lapilli at $4 \mathrm{~km}$ from the vent (U17/773863) (Table 1, sample 7); and the late-stage lava dome (U17/761903) (Table 1, sample 8). Puketarata Tephra is characterised by biotite $>>$ hornblende $>$ cummingtonite + hypersthene FMA. All of the pyroclastic samples have the same $\mathrm{K}_{2} \mathrm{O}$-rich (c. 4.0-4.4 wt\%) glass composition (Table 1, Fig. 2B). We combined analyses of samples collected vertically through the pyroclastic deposits (samples 7 and 8 ) because the data do not vary more than analytical uncertainty. The $\mathrm{K}_{2} \mathrm{O}$ content of Puketarata Tephra glass is similar to, but slightly lower than, the high- $\mathrm{K}_{2} \mathrm{O}$ glass of Rotorua Tephra (Fig. 2B). The Puketarata lava dome samples display slightly higher $\mathrm{K}_{2} \mathrm{O}$ content (c. 4.4-4.6 wt\%) than those of the pyroclastics, but are similar in all other elements (Table 1). 


\section{Biotite composition}

Little has been previously published on the composition of biotite in rhyolites erupted in the TVZ. We made electron microprobe analyses of biotite from various deposits of the Rotorua eruptive episode (see above), from proximal-medial Puketarata eruptives, and the $15700 \mathrm{cal}$ yr BP tephra bed at Kaipo (Table 2). Typical analytical totals are in the range 94-96 wt \%, with the discrepancy from $100 \%$ considered due to unanalysed anions $\mathrm{OH}$ and $\mathrm{F}$, and other minor elements such as Ba (e.g., Righter et al. 2002). Formulae calculated based on 22 oxygens assuming idealised anions give cation totals of $\mathrm{I}=1.8-1.9, \mathrm{M}=5.6-5.8$, and $\mathrm{T}=8.0$, which are typical of biotite compositions (e.g., Deer et al. 1966). Biotite in Puketarata pyroclastics can be distinguished from that in Rotorua Tephra by its generally lower FeO content (Fig. 2C). However, biotites from the Puketarata lava dome plot within the compositional field of those from Rotorua Tephra.

\section{CORRELATION OF THE 15700 CAL YR BP TEPHRA BED AT KAIPO}

Our analyses of glass shards, replicated using different samples and separate electron microprobe systems (Table 1, Fig. 2A,B), indicate correlation of the tephra bed at Kaipo with the Rotorua Tephra. The tephra at Kaipo contains two populations of glass, both of which match the compositions recorded for Rotorua Tephra. The predominant Kaipo population (Table 1, samples 9a and 10a) has high $\mathrm{K}_{2} \mathrm{O}$ $(>4 \mathrm{wt} \%)$ and low $\mathrm{CaO}(<1 \mathrm{wt} \%)$, which corresponds to the late stage Rotorua eruption events (Fig. 2B). The minor population (Table 1 , samples $9 \mathrm{~b}$ and $10 \mathrm{~b}$ ) has low $\mathrm{K}_{2} \mathrm{O}$ $(<4 \mathrm{wt} \%)$ and high $\mathrm{CaO}(>1 \mathrm{wt} \%)$, which corresponds to the early stage Rotorua eruption events (Fig. 2B). In addition, glass in the predominant (high- $\mathrm{K}_{2} \mathrm{O}$ ) Kaipo population generally has a slightly higher $\mathrm{K}_{2} \mathrm{O}$ content than glass from pyroclastic deposits of Puketarata Tephra (Fig. 2B).

Biotite crystals in the tephra bed at Kaipo display higher $\mathrm{FeO}$ contents than those in proximal pyroclastic deposits of Puketarata Tephra but compositionally match those of Rotorua Tephra (Fig. 2C). However, they are also similar to Puketarata lava dome biotite.

The Puketarata lava dome contains glass of higher $\mathrm{K}_{2} \mathrm{O}$ content and biotite of higher $\mathrm{FeO}$ content than the Puketarata pyroclastics, and is compositionally similar to the high- $\mathrm{K}_{2} \mathrm{O}$ glass and high-FeO biotite within late-stage Rotorua Tephra (Fig. 2). The $\mathrm{K}_{2} \mathrm{O}$ content in the glass of Puketarata lava may have been affected by vapour-phase alteration during slow cooling, because the glass does not differ significantly in other elemental abundances. Prolonged cooling may also

Table 1 Electron microprobe analyses of glass shards from Rotorua Tephra, Puketarata Tephra, and the tephra at Kaipo Bog.

\begin{tabular}{|c|c|c|c|c|c|c|c|c|c|c|c|c|c|c|}
\hline & 1 & & 2 & & 3 & & 4 & & $5 a$ & & $5 b$ & & 6 & \\
\hline $\mathrm{SiO}_{2}$ & 76.43 & 0.28 & 77.55 & 0.21 & 77.53 & 0.16 & 77.36 & 0.17 & 77.44 & 0.31 & 76.57 & 0.28 & 77.50 & 0.23 \\
\hline $\mathrm{Al}_{2} \mathrm{O}_{3}$ & 12.60 & 0.14 & 12.34 & 0.11 & 12.25 & 0.10 & 12.27 & 0.14 & 12.27 & 0.08 & 12.59 & 0.12 & 12.23 & 0.13 \\
\hline $\mathrm{TiO}_{2}$ & 0.31 & 0.07 & 0.10 & 0.05 & 0.10 & 0.06 & 0.18 & 0.08 & 0.15 & 0.02 & 0.30 & 0.07 & 0.13 & 0.08 \\
\hline $\mathrm{FeO}$ & 1.39 & 0.11 & 0.78 & 0.10 & 0.82 & 0.08 & 0.83 & 0.10 & 0.94 & 0.13 & 1.38 & 0.11 & 0.86 & 0.14 \\
\hline $\mathrm{MnO}$ & 0.07 & 0.06 & 0.08 & 0.04 & 0.08 & 0.05 & 0.07 & 0.06 & 0.09 & 0.06 & 0.07 & 0.07 & 0.07 & 0.05 \\
\hline $\mathrm{MgO}$ & 0.25 & 0.06 & 0.05 & 0.05 & 0.07 & 0.04 & 0.05 & 0.05 & 0.08 & 0.04 & 0.26 & 0.10 & 0.05 & 0.05 \\
\hline $\mathrm{CaO}$ & 1.34 & 0.07 & 0.65 & 0.04 & 0.65 & 0.06 & 0.69 & 0.05 & 0.78 & 0.08 & 1.33 & 0.07 & 0.75 & 0.05 \\
\hline $\mathrm{Na}_{2} \mathrm{O}$ & 4.45 & 0.10 & 3.92 & 0.07 & 3.92 & 0.09 & 3.98 & 0.11 & 3.76 & 0.23 & 4.28 & 0.15 & 4.02 & 0.09 \\
\hline $\mathrm{K}_{2} \mathrm{O}$ & 3.01 & 0.06 & 4.37 & 0.06 & 4.42 & 0.07 & 4.39 & 0.08 & 4.27 & 0.11 & 3.08 & 0.08 & 4.19 & 0.11 \\
\hline $\mathrm{Cl}$ & 0.16 & 0.03 & 0.15 & 0.03 & 0.14 & 0.05 & 0.16 & 0.03 & 0.22 & 0.07 & 0.14 & 0.04 & 0.20 & 0.04 \\
\hline $\mathrm{H}_{2} \mathrm{O}$ & 4.84 & 1.00 & 2.26 & 0.38 & 3.15 & 0.98 & 2.14 & 0.55 & 7.32 & 2.19 & 6.19 & 1.32 & 3.10 & 1.35 \\
\hline \multirow[t]{2}{*}{$n$} & 13 & & 10 & & 10 & & 10 & & 4 & & 15 & & 17 & \\
\hline & 7 & & 8 & & $9 a$ & & $9 b$ & & $10 \mathrm{a}$ & & $10 \mathrm{~b}$ & & & \\
\hline $\mathrm{SiO}_{2}$ & 77.24 & 0.18 & 77.13 & 0.14 & 77.42 & 0.19 & 76.55 & 0.26 & 77.71 & 0.36 & 76.76 & & & \\
\hline $\mathrm{Al}_{2} \mathrm{O}_{3}$ & 12.30 & 0.10 & 12.27 & 0.12 & 12.40 & 0.10 & 12.74 & 0.22 & 12.57 & 0.05 & 13.15 & & & \\
\hline $\mathrm{TiO}_{2}$ & 0.10 & 0.06 & 0.10 & 0.05 & 0.14 & 0.06 & 0.34 & 0.12 & 0.08 & 0.20 & 0.20 & & & \\
\hline $\mathrm{FeO}$ & 0.92 & 0.11 & 0.91 & 0.08 & 0.77 & 0.12 & 1.31 & 0.10 & 0.82 & 0.06 & 1.43 & & & \\
\hline $\mathrm{MnO}$ & 0.08 & 0.06 & 0.10 & 0.04 & 0.10 & 0.05 & 0.09 & 0.07 & 0.14 & 0.08 & 0.09 & & & \\
\hline $\mathrm{MgO}$ & 0.06 & 0.06 & 0.06 & 0.03 & 0.08 & 0.06 & 0.24 & 0.06 & 0.08 & 0.02 & 0.18 & & & \\
\hline $\mathrm{CaO}$ & 0.75 & 0.07 & 0.74 & 0.03 & 0.67 & 0.07 & 1.38 & 0.04 & 0.66 & 0.06 & 1.20 & & & \\
\hline $\mathrm{Na}_{2} \mathrm{O}$ & 4.08 & 0.12 & 4.05 & 0.14 & 3.87 & 0.09 & 4.20 & 0.13 & 3.55 & 0.21 & 3.93 & & & \\
\hline $\mathrm{K}_{2} \mathrm{O}$ & 4.25 & 0.08 & 4.47 & 0.11 & 4.39 & 0.06 & 3.03 & 0.10 & 4.20 & 0.13 & 2.89 & & & \\
\hline $\mathrm{Cl}$ & 0.18 & 0.03 & 0.17 & 0.04 & 0.16 & 0.03 & 0.13 & 0.08 & 0.19 & 0.03 & 0.17 & & & \\
\hline $\mathrm{H}_{2} \mathrm{O}$ & 4.36 & 1.68 & 2.93 & 0.49 & 4.90 & 1.13 & 4.45 & 0.85 & 1.85 & 1.26 & 2.30 & & & \\
\hline$n$ & 26 & & 10 & & 11 & & 4 & & 11 & & 1 & & & \\
\hline
\end{tabular}

1 = Rotorua pumice clast, pumice pit site (U16/017317); 2 = Rotorua pumice clast, site 102 (U16/025256), 3 = Rotorua lava, Trig 7693 (U16/027284), 4 = Rotorua lava clast, Te Mu Rd block-and-ash flow deposit (U16/048273); 5 = Rotorua Tephra, Onepoto Basin (R11/ 666866); $6=$ Puketarata lapilli basal and upper (U17/753900); $7=$ Puketarata ash base, middle and top (U17/773863); $8=$ Puketarata lava (U17/761903); 9 = Kaipo Bog tephra, depth 4.17-4.18 m (W18/739717); 10 = duplicate analysis of Kaipo Bog tephra.

Analyses are recalculated to $100 \%$ on a volatile free basis and expressed as a mean and standard deviation (italics) in wt $\%$. Total Fe as FeO. Water by difference. $n=$ number of shards analysed.

Samples 1-9 analysed by a Jeol JXA-840 probe fitted with a PGT Prism 2000 EDS detector at University of Auckland. Absorbed current of $1.5 \mathrm{nA}$ at $15 \mathrm{kV}$ and a beam defocused to $15 \mu \mathrm{m}$. Analysts: P. Shane and V. Smith. Sample 10 analysed by a Jeol JXA-733 probe at Victoria University of Wellington. Current of $8 \mathrm{nA}$ at $15 \mathrm{kV}$ and a beam defocused to $10-15 \mu \mathrm{m}$. Analyst: D. Manning. 

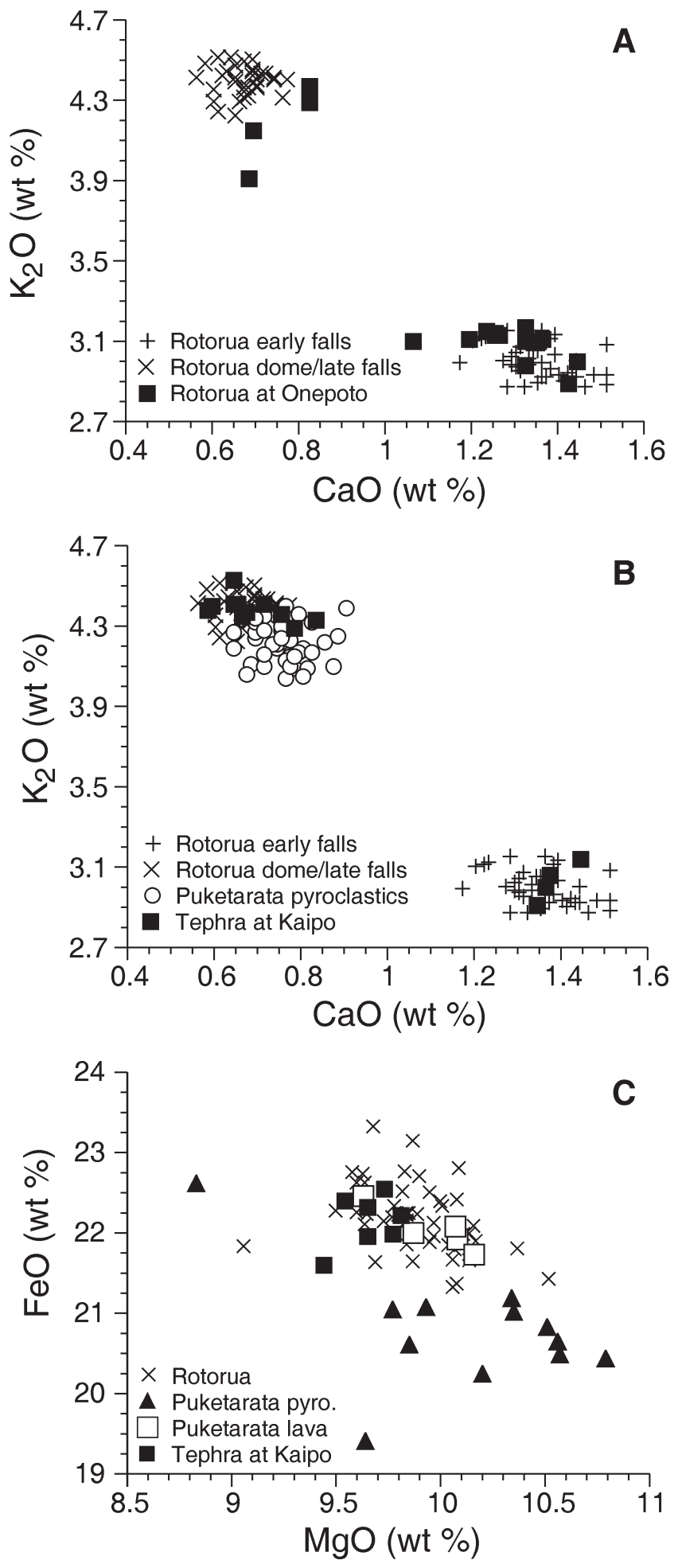

Fig. 2 A, Compositions of single glass shards in Rotorua Tephra deposits. B, Compositions of single glass shards in proximal Rotorua deposits compared with those of Puketarata Tephra and of the tephra bed at Kaipo Bog. C, Compositions of single biotite phenocrysts/crystals in Rotorua deposits, Puketarata Tephra, and the tephra bed at Kaipo Bog. have resulted in re-equilibration of the biotite. Neither of these processes would have occurred in any associated pyroclastics. We have found no proximal-medial Puketarata Tephra with this higher $\mathrm{K}_{2} \mathrm{O}$ composition, and do not consider the dome extrusion phase to have been capable of widely dispersing ash that would have been compositionally different from that of the main pyroclastic phase of Puketarata.

\section{DISCUSSION AND CONCLUSIONS}

The identification of two glass populations in the c. 15700 cal yr BP tephra at Kaipo Bog rules out its previous identification as Puketarata Tephra, despite some partial overlap of chemical compositions. The glass compositions, together with biotite analyses, radiocarbon ages, and stratigraphic position, strongly support correlation to Rotorua Tephra now recognised to have a bimodal glass composition. The age of c. $13100{ }^{14} \mathrm{C}$ yr BP (= c. 15700 cal yr BP) estimated for the tephra bed at Kaipo using sedimentation rates and tephrochronology (Lowe et al. 1999) is consistent with the pooled radiocarbon age of Rotorua Tephra of 13080 $\pm 50(n=10)$ reported by Froggatt \& Lowe (1990). The new correlation of the Rotorua Tephra at Kaipo eliminates the requirement to either revise the age of Puketarata Tephra or to invoke a scenario of two "Puketarata Tephra" eruptions occurring c. $1000 \mathrm{yr}$ apart, as was tentatively suggested by Lowe et al. (1999). Apart from identification of the tephra in the Waikato region some $90 \mathrm{~km} \mathrm{NNW}$ of the vent (Lowe 1988a), dispersal of Puketarata Tephra (sensu stricto) remains well constrained only close to its source (Wilson et al. 1986). Topping \& Kohn (1973) tentatively identified Puketarata Tephra in the Tongariro region $60-80 \mathrm{~km}$ south of the vent. However, subsequent studies in this region do not record this tephra (e.g., Donoghue et al. 1995; Cronin et al. 1997). We conclude that Puketarata Tephra has a limited dispersal and was probably the product of a single eruptive episode.

The new glass chemistry data for Rotorua eruptives demonstrate that two distinct magmas were involved in the eruption: (1) a low- $\mathrm{K}_{2} \mathrm{O}$ magma dominant in the earlyerupted plinian pumice and ash; and (2) a high- $\mathrm{K}_{2} \mathrm{O}$, biotitebearing magma forming the later erupted lava extrusions and their accompanying pyroclastic ejecta component. Kilgour (2002) also noted (from whole rock compositions) that earlyphase plinian fall deposits, dispersed primarily to the northwest, are relatively low in $\mathrm{SiO}_{2}$ in comparison with latephase dome-building lavas.

Loose biotite crystals are found throughout the Rotorua proximal plinian pumice fall deposits, but biotite-bearing clasts occur only in the middle to upper parts of the proximal plinian fall sequence. The compositional contrast can be used to trace dispersal of the ash as the eruption proceeded. Our preliminary studies show that low- $\mathrm{K}_{2} \mathrm{O}$ plinian ejecta were deposited predominantly to northwest of the vent, as found at the pumice pit site and Onepoto Basin (Fig. 1). They comprise most of the Rotorua plinian deposits as mapped by Pullar (1972), Nairn (1980), and Lowe (1988a). The later stage, high- $\mathrm{K}_{2} \mathrm{O}$ ejecta dominates Rotorua fall sequences to the south, at Te Mu Road, site 102, and Kaipo (Fig. 1). However, some variation within the distal fall deposits indicates complexity within the dispersal processes. Four of the 19 glass shards analysed from Onepoto Basin $(160 \mathrm{~km}$ NNW of the vent) are of the high- $\mathrm{K}_{2} \mathrm{O}$ (late-erupted) type (the 15 others are the low- $\mathrm{K}_{2} \mathrm{O}$ early type), whereas 22 of 27 
Table 2 Electron microprobe analyses of biotite from Rotoura Tephra, Puketarata Tephra, and the tephra at Kaipo Bog.

\begin{tabular}{|c|c|c|c|c|c|c|c|c|c|c|c|c|c|c|}
\hline & 1 & & 2 & & 3 & & 4 & & 5 & & 6 & & 7 & \\
\hline $\mathrm{SiO}_{2}$ & 35.78 & 0.68 & 35.87 & 0.32 & 36.06 & 0.26 & 35.75 & 0.19 & 36.04 & 0.34 & 36.17 & 0.22 & 35.53 & 0.37 \\
\hline $\mathrm{TiO}_{2}$ & 4.73 & 0.26 & 4.69 & 0.18 & 4.78 & 0.15 & 4.69 & 0.20 & 4.50 & 0.26 & 4.87 & 0.09 & 4.67 & 0.14 \\
\hline $\mathrm{Al}_{2} \mathrm{O}_{3}$ & 13.23 & 0.25 & 13.30 & 0.21 & 13.38 & 0.60 & 13.39 & 0.17 & 13.62 & 0.59 & 13.39 & 0.11 & 13.27 & 0.18 \\
\hline $\mathrm{FeO}$ & 22.51 & 0.46 & 22.43 & 0.46 & 22.38 & 0.23 & 22.05 & 0.30 & 20.91 & 0.81 & 22.04 & 0.27 & 22.15 & 0.32 \\
\hline $\mathrm{MnO}$ & 0.46 & 0.05 & 0.49 & 0.07 & 0.37 & 0.12 & 0.37 & 0.14 & 0.31 & 0.10 & 0.36 & 0.09 & 0.43 & 0.06 \\
\hline $\mathrm{MgO}$ & 9.77 & 0.20 & 9.86 & 0.14 & 9.86 & 0.22 & 10.03 & 0.11 & 10.10 & 0.52 & 9.95 & 0.21 & 9.65 & 0.13 \\
\hline $\mathrm{CaO}$ & 0.09 & 0.08 & 0.04 & 0.03 & 0.09 & 0.05 & 0.06 & 0.06 & 0.09 & 0.07 & 0.03 & 0.01 & 0.13 & 0.08 \\
\hline $\mathrm{Na}_{2} \mathrm{O}$ & 0.40 & 0.11 & 0.46 & 0.15 & 0.36 & 0.10 & 0.40 & 0.11 & 0.35 & 0.07 & 0.29 & 0.09 & 0.29 & 0.11 \\
\hline $\mathrm{K}_{2} \mathrm{O}$ & 8.43 & 0.14 & 8.43 & 0.09 & 8.46 & 0.18 & 8.46 & 0.10 & 8.20 & 0.24 & 8.39 & 0.14 & 8.19 & 0.21 \\
\hline $\mathrm{Cl}$ & 0.33 & 0.03 & 0.29 & 0.06 & 0.30 & 0.03 & 0.30 & 0.04 & 0.33 & 0.04 & 0.30 & 0.04 & 0.29 & 0.02 \\
\hline total & 95.72 & 1.55 & 95.86 & 0.63 & 96.05 & 0.70 & 95.49 & 0.33 & 94.44 & 0.88 & 95.78 & 0.41 & 94.60 & 0.96 \\
\hline$n$ & 6 & & 6 & & 6 & & 5 & & 13 & & 5 & & 7 & \\
\hline $\mathrm{Si}$ & 5.55 & 0.03 & 5.55 & 0.05 & 5.57 & 0.02 & 5.55 & 0.03 & 5.61 & 0.03 & 5.58 & 0.03 & 5.57 & 0.02 \\
\hline $\mathrm{Ti}$ & 0.55 & 0.02 & 0.55 & 0.02 & 0.56 & 0.02 & 0.55 & 0.03 & 0.53 & 0.03 & 0.56 & 0.01 & 0.55 & 0.02 \\
\hline $\mathrm{Al}$ & 2.42 & 0.01 & 2.42 & 0.03 & 2.43 & 0.09 & 2.45 & 0.03 & 2.49 & 0.10 & 2.43 & 0.01 & 2.45 & 0.03 \\
\hline $\mathrm{Fe}$ & 2.92 & 0.06 & 2.90 & 0.05 & 2.89 & 0.05 & 2.86 & 0.04 & 2.72 & 0.11 & 2.85 & 0.04 & 2.90 & 0.03 \\
\hline $\mathrm{Mn}$ & 0.07 & 0.01 & 0.07 & 0.01 & 0.05 & 0.02 & 0.04 & 0.02 & 0.04 & 0.02 & 0.04 & 0.02 & 0.06 & 0.01 \\
\hline $\mathrm{Mg}$ & 2.26 & 0.04 & 2.28 & 0.02 & 2.26 & 0.07 & 2.32 & 0.02 & 2.34 & 0.11 & 2.28 & 0.04 & 2.25 & 0.02 \\
\hline $\mathrm{Ca}$ & 0.01 & 0.02 & 0.00 & 0.01 & 0.01 & 0.01 & 0.01 & 0.01 & 0.02 & 0.01 & 0.00 & 0.00 & 0.02 & 0.01 \\
\hline $\mathrm{Na}$ & 0.12 & 0.03 & 0.14 & 0.04 & 0.11 & 0.03 & 0.12 & 0.03 & 0.11 & 0.02 & 0.09 & 0.03 & 0.09 & 0.03 \\
\hline K & 1.66 & 0.03 & 1.66 & 0.02 & 1.67 & 0.03 & 1.67 & 0.02 & 1.63 & 0.05 & 1.65 & 0.03 & 1.64 & 0.04 \\
\hline $\mathrm{Cl}$ & 0.09 & 0.00 & 0.08 & 0.01 & 0.08 & 0.01 & 0.08 & 0.01 & 0.09 & 0.01 & 0.08 & 0.01 & 0.08 & 0.01 \\
\hline total & 15.65 & 0.05 & 15.63 & 0.07 & 15.62 & 0.06 & 15.63 & 0.05 & 15.57 & 0.07 & 15.56 & 0.09 & 15.60 & 0.05 \\
\hline I & 1.89 & & 1.88 & & 1.87 & & 1.8 & & 1.8 & & 1.82 & & 1.82 & \\
\hline M & 5.80 & & 5.79 & & 5.76 & & 5.77 & & 5.63 & & 5.73 & & 5.76 & \\
\hline $\mathrm{T}$ & 8.00 & & 8.00 & & 8.00 & & 8.00 & & 8.00 & & 8.00 & & 8.00 & \\
\hline
\end{tabular}

1 = Rotorua pumice clast, site 102 (U16/025256), 2 = Rotorua lava, Trig 7693 (U16/027284), 3 = Rotorua lava clast, Te Mu Rd blockand-ash flow deposit (U16/048273); 4 = Rotorua Tephra, Onepoto Basin (R11/666866); 5 = Puketarata lapilli base and upper (U17/ 753900); 6 = Puketarata lava (U17/761903); 7 = Kaipo Bog tephra, depth 4.17-4.18 m (W18/739717).

Presented as a mean and standard deviation (italics). $n=$ number of crystals analysed. Oxides in wt $\%$ and cations in atoms per unit formula on the basis of 22 oxygens.

Analysed by a Jeol JXA-840 probe fitted with a PGT Prism 2000 EDS detector at University of Auckland. Absorbed current of $1.5 \mathrm{nA}$ at $15 \mathrm{kV}$ and a focused beam. Analysts: P. Shane and V. Smith.

glass shards analysed from Kaipo Bog (100 km southeast of the vent) are of the high- $\mathrm{K}_{2} \mathrm{O}$ type. Minor amounts of the "opposite" glass type are dispersed to both the northwest and southeast distal sites. This suggests that reversals in wind directions and/or wind shear at different altitudes must have occurred during the early Rotorua plinian eruptions, and during the explosive pyroclastic activity associated with the late phase lava extrusions.

Geochemical fingerprinting is likely to be problematic where unrecognised changes in magma composition and dispersal direction occurred as an eruption proceeded. However, the variation in chemical characteristics, once recognised, actually enhances the potential for correlation by increasing the number of fingerprinting parameters. In the Kaipo Bog case, detailed stratigraphically controlled studies of variations in glass chemistry, in combination with biotite compositions, have been required to identify a thin rhyolite tephra in a distal setting.

\section{ACKNOWLEDGMENTS}

VS acknowledges funding from the University Federation of Graduate Women and FRST (Bright Futures Scholarship). This work was partially funded by the Foundation for Science, Research and Technology contract IANX0001. Brent Alloway is thanked for his comments.

\section{REFERENCES}

Allen, K. 1988: A stratigraphic analysis of the chemical and mineralogical variations of the Rotorua Ash, North Island, New Zealand. Unpublished BSc dissertation, Victoria University of Wellington, Wellington. $45 \mathrm{p}$.

Brooker, M. R.; Houghton, B. F.; Wilson, C. J. N.; Gamble, J. A. 1993: Pyroclastic phases of a rhyolitic dome-building eruption: Puketarata tuff ring, Taupo Volcanic Zone, New Zealand. Bulletin of Volcanology 55: 395-406.

Cronin, S. J.; Neall, V. E.; Palmer, A. S.; Stewart, R. B. 1997: Methods of identifying late Quaternary rhyolitic tephras on the ring plains of Ruapehu and Tongariro volcanoes, New Zealand. New Zealand Journal of Geology and Geophysics 40: 175-184.

Deer, W. A.; Howie, R. A.; Zussman, J. 1966: An introduction to the rock-forming minerals. Harlow, Longman. 528 p.

Donoghue, S. L.; Neall, V. E.; Palmer, A. S. 1995: Stratigraphy and chronology of late Quaternary andesitic tephra deposits, Tongariro Volcanic Centre, New Zealand. Journal of the Royal Society of New Zealand 25: 115-206.

Froggatt, P. C.; Lowe, D. J. 1990: A review of late Quaternary silicic and some other tephra formations from New Zealand: their stratigraphy, nomenclature, distribution, volume, and age. New Zealand Journal of Geology and Geophysics 33: 89-109.

Kilgour, G. N. 2002: The nature and dynamics of the Rotorua eruptive episode, Okataina Volcanic Zone, Taupo Volcanic Zone. Unpublished MSc thesis, University of Waikato, Hamilton, New Zealand. 
Lloyd, E. F. 1972: Geology and hot springs of Orakeikorako. New Zealand Geological Survey Bulletin 85.

Lowe, D. J. 1988a: Stratigraphy, age, composition, and correlation of late Quaternary tephras interbedded with organic sediments in Waikato lakes, North Island, New Zealand. New Zealand Journal of Geology and Geophysics 31: 125165.

Lowe, D. J. 1988b: Late Quaternary volcanism in New Zealand: towards an integrated record using distal airfall tephras in lakes and bogs. Journal of Quaternary Science 3: 111-120.

Lowe, D. J.; Hogg, A. G. 1986: Tephrostratigraphy and chronology of the Kaipo Lagoon, an 11,500 year-old montane peat bog in Urewera National Park, New Zealand. Journal of the Royal Society of New Zealand 16: 25-41.

Lowe, D. J.; Newnham, R. M.; Ward, C. M. 1999: Stratigraphy and chronology of a 15 ka sequence of multi-sourced silicic tephras in a montane peat bog, eastern North Island, New Zealand. New Zealand Journal of Geology and Geophysics 42: 565-579.

Nairn, I. A. 1980: Source, age, and eruptive mechanisms of Rotorua Ash. New Zealand Journal of Geology and Geophysics 23 193-207.

Newnham, R. M.; Lowe, D. J. 2000: Fine-resolution pollen record of late-glacial climate reversal from New Zealand. Geology 28: 759-762.
Pullar, W. A. 1972: Isopachs of tephra, central North Island, New Zealand. Scale 1: 1000 000. N.Z. Soil Bureau maps 133/ 8-14. N.Z. Soil Survey Report 1.

Righter, K.; Darby-Dyar, M.; Delaney, J. S.; Vennemann, T. W.; Hervig, R. L.; King, P. L. 2002: Correlation of octahedral cations with $\mathrm{OH}^{-}, \mathrm{O}^{2-}, \mathrm{Cl}^{-}$, and $\mathrm{F}^{-}$in biotite from volcanic rocks and xenoliths. American Mineralogist 87: 142-153.

Shane, P. A. R. 1998: Correlation of rhyolitic pyroclastic eruptive units from the Taupo Volcanic Zone, New Zealand, by FeTi oxide compositional data. Bulletin of Volcanology 60: 224-238.

Shane, P.; Hoverd, J. 2002: Distal record of multi-sourced tephra in Onepoto Basin, Auckland: implications for volcanic chronology, frequency and hazards. Bulletin of Volcanology 64: 441-454.

Stuiver, M.; Reimer, P. J.; Bard, E.; Beck, J. W.; Burr, G. S.; Hughen, K. A.; Kromer, B.; McCormac, G.; van der Plicht, J.; Spurk, M. 1998: INTCAL98 radiocarbon age calibration, 24,0000 cal BP. Radiocarbon 40: 1041-1083.

Topping, W. W.; Kohn, B. P. 1973: Rhyolitic tephra marker beds in the Tongariro area, North Island, New Zealand. New Zealand Journal of Geology and Geophysics 16: 375-395.

Wilson, C. J. N.; Houghton, B. F.; Lloyd, E. F. 1986: Volcanic history and evolution of the Maroa-Taupo area, central North Island. Royal Society of New Zealand Bulletin 23: 194-223. 